\title{
АКТУАЛЬНІ ПИТАННЯ ПРАВОВОГО РЕГУЛЮВАННЯ ІНФОРМАЦІЙНИХ ВІДНОСИН В УКРАЇНІ
}

Грохольський В. Л.

Наукову статтю присвячено досить важливій проблемі сьогодення - розгляду актуальних питань правового регулювання інформаційних відносин в Україні. Визначено роль інформаційних відносин e розвитку політичних, економічних, соціальних, правових та інших процесів. Зазначено, що стрімкі інформаційні процеси, що відбуваються сьогодні, мають як позитивні, так і негативні наслідки. Автором підкреслено, що зменшення негативних наслідків в інформаційних процесах потребує чіткого правового регулювання таких відносин. Наголошено, що правове регулювання становить фундамент у будь-яких відносинах, інформаційні правовідносини не є винятком.

3'ясовано значення слова «регулювати», наголошено, що суспільні відносини, які пов'язані з обігом інформаціі, недоречно розглядати лише як систему заборон та обмежень.

Проаналізовано законодавче визначення інформатизації, розглянуто правове регулювання інформаційних відносин, що міститься в законодавчих актах України.

Проаналізовано наукові джерела та законодавчі акти щодо правового регулювання інформаційних відносин у публічній та приватній сферах. Приділена увага договірним відносинам у регулюванні інформаційних відносин.

Визначено роль і значення соціальної реклами у формуванні громадянського суспільства. Звернута увага на те, що в сучасному світі можливе необ'єктивне подання відомостей, адже за допомогою таких інструментів, як засоби масової інформації, кіноіндустрія, інформація може бути спотворена, перекручена залежно від інтересів власника засобу масової інформаціі, інтересів інших зацікавлених осіб. Наголошено, що в такому разі якраз чітке регулювання інформаційних відносин має надзвичайно велике значення.

Автором приділено увагу розгляду наукової дискусії щодо визначення інформаційного права як самостійної галузі права, наголошено на його міжгалузевому значені.

Зроблено висновок, що під правовим регулюванням інформаційних відносин варто розуміти наявність міжгалузевих правових норм, які регулюють публічно-приватні відносини щодо створення, збирання, зберігання, поширення, використання, знищення тощо інформації, на підставі яких виникають правові інформаційні відносини між суб'єктами.

Ключові слова: інформація, інформаційне право, правове регулювання інформаційних відносин.
Groholskyi V. L. Current issues of legal regulation of information relations in Ukraine

The scientific article is devoted to a very important problem of today - consideration of topical issues of legal regulation of information relations in Ukraine. The role of information relations in the development of political, economic, social, legal and other processes is determined. It is noted that the rapid information processes taking place today have both positive and negative consequences. The author emphasizes that the reduction of negative consequences in information processes requires a clear legal regulation of such relations. It is emphasized that legal regulation is the foundation in any relationship, and information relations are no exception.

The meaning of the word "regulate" is clarified and it is emphasized that public relations, which are connected with the circulation of information, should not be considered only as a system of prohibitions and restrictions.

The legislative definition of informatization is analyzed and the legal regulation of information relations contained in the legislative acts of Ukraine is considered.

Scientific sources and legislative acts on the legal regulation of information relations in the public and private spheres are analyzed. Attention is paid to contractual relations in the regulation of information relations.

The role and significance of social advertising in the formation of civil society is determined. It is noted that in today's world, the possible presentation of information is not objective enough, because with tools such as the media, film industry, information can be distorted or distorted, depending on the interests of the media owner and the interests of other stakeholders. It is emphasized that in such cases clear regulation of information relations is extremely important.

The author pays attention to the scientific discussion on the definition of information law as an independent branch of law and emphasizes its intersectoral significance.

It is concluded that the legal regulation of information relations should be understood as the presence of intersectoral legal norms governing public-private relations for the creation, collection, storage, distribution, use, destruction and other actions with information, on the basis of which legal information relations arise. objects.

Key words: information, information law, legal regulation of information relations. 
Постановка проблеми та іï актуальність. Інформація відіграє важливу роль у розвитку політичних, економічних, соціальних, правових та інших процесів не тільки в Україні, а в усьому світі. Важко сьогодні уявити діяльність будь-якого державного органу влади, місцевого самоврядування, державних і недержавних установ, громадських об'єднань і окремо взятих громадян, що не мають доступу до інформації і не використовують їі. Водночас стрімкі інформаційні процеси мають як позитивні, так і негативні наслідки. Зменшення негативних наслідків потребує чіткого правового регулювання інформаційних відносин, що виникають між різними суб'єктами. Тому правове регулювання становить фундамент у будьяких відносинах, інформаційні правовідносини не $\epsilon$ винятком. У цій сфері, що стрімко розвивається, $\epsilon$ чимало питань, які потребують правового регулювання. Нині, на жаль, з об'єктивних причин правове регулювання дещо відстає від стрімкого розвитку інформаційних технологій та інформаційних відносин. Неузгодженість формування законодавства із цих питань призвела до наявності окремих проблем як теоретичного, так і практичного значення, зокрема щодо знаходження балансу в інформаційних відносинах між приватними та публічними інтересами тощо. Вирішення наявних проблем потребує наукового розгляду й обґрунтування.

Аналіз останніх досліджень i публікацій. Зазначимо, що дослідженню питань правового регулювання інформаційних відносин в Україні приділяли увагу науковці, які здійснюють дослідження не тільки у сфері інформаційного права, а й інших галузей права. Зокрема, питанням інформаційних відносин присвячено праці І.В. Арістової, О.А. Баранова, О.М. Бандурки, К.І. Бєлякова, К.Ю. Ісмайлова, Р.А. Калюжного, Л.П. Коваленко, Б.А. Кормича, А.М. Новицького, Д.О. Перова, В.Г. Пилипчука, В.І. Плахтєєвої, В.С. Політанського, О.С. Селезньової, Р.В. Тарасенка, О.О. Тихомирова, В.С. Цимбалюка, М.Я. Швеця, П.М. Рабіновича, О.Ф. Скакун, В.К. Колпакова, В.І. Литвиненка, Т.А. Литвиненко, А.В. Форос та інших. Але, незважаючи на наявні праці, натепер залишається багато неврегульованих питань 3 інформаційних відносин, що потребує наукового дослідження.

Метою статті $\epsilon$ дослідження актуальних питань правового регулювання інформаційних відносин в Україні, визначення ролі правового регулювання в таких відносинах, постановка проблеми щодо необхідності розвитку й удосконалення правового регулювання інформаційних відносин.
Виклад основного матеріалу. Слово «регулювати» походить від лат. regulo - «упорядковувати», «вносити порядок, систему в якусь діяльність». «Регулятор», у переносному значенні, - те, що сприяє упорядкуванню, упровадженню певного порядку, системи (норми, стандарти, інструкції) [1, с. 574]. На думку Е.М. Пенькова, регулювати підкорювати життєдіяльність суспільства певним правилам - вимогам (суб'єктивний чинник), зміст яких зумовлений насамперед економічними відносинами суспільства (об'єктивний чинник). У результаті регулювання досягають упорядкування, закріплення та розвитку суспільних відносин, визначеної спрямованості всієї соціальної діяльності людей [2, с. 11]. О.С. Йоффе зазначав, що регулювання суспільних відносин полягає у встановленні рамок, меж поведінки їх учасників [3, с. 10]. Водночас суспільні відносини, що пов'язані з обігом інформації, недоречно розглядати лише як систему заборон та обмежень. На сучасному етапі вже йдеться про стимулювання і сприяння держави у встановлені саморегулювання таких відносин, що пов'язується не лише із заборонами чи обмеженнями, а деякою мірою з договірними відносинами. Тому нині можна говорити про те, що регулювання інформаційних відносин відбувається не лише владним впливом держави на ці відносини, а передбачає застосування складної системи спеціальних засобів та методів.

Проблеми правового регулювання інформаційних відносин актуалізуються й тим, що нині неоднозначними є підходи до розуміння інформації й інформаційних відносин. Так, у «Словнику-довіднику юридичних термінів» за редакцією T.А. Литвиненко, В.І. Плахтєєвої інформацію визначено як документовані або публічно оголошені відомості про події та явища, що відбулись або відбуваються в суспільстві, державі та навколишньому середовищі [4, с. 54]. О.В. Кохановська вважає, що інформація, будучи нематеріальною за своєю сутністю, є першоджерелом і поясненням усього, що існує у світі. Далі авторка зазначає, що через таке глибинне розуміння інформації можливе вирішення цілого комплексу як загальнотеоретичних, філософських, так і правових проблем [5, с. 13]. У Правовій доктрині України інформація визначається як фундаментальна, універсальна й основоположна величина, що становить основу світобудови [6, с. 755].

К.І. Бєляков звертає увагу на те, що нерідко на практиці, особливо в законодавстві, неправомірно (нераціонально) встановлюють однозначність, ототожнення категорій «дані», «відомості», 
«інформація», «знання». 3 одного боку, визначення «дані» та «відомості» за своєю суттю $є$ синонімами, які часто вживають не лише в побутовому спілкуванні, а й, на жаль, у наукових дослідженнях. Як об'єкти правового регулювання поняття «дані», «відомості», «інформація» $\epsilon$ різними $[7$, c. 43,44$]$. Є.В. Петров інформацію визначає як відомості (а не дані) про події та явища, які може пізнати особа та передати іншій особі у вигляді, придатному для сприйняття [8, с. 9].

У загальних положеннях Закону України «Про Концепцію Національної програми інформатизації» визначається, що інформатизація - це сукупність взаємопов'язаних організаційних, правових, політичних, соціально-економічних, науково-технічних, виробничих процесів, спрямованих на створення умов для задоволення інформаційних потреб, реалізації прав громадян і суспільства на основі створення, розвитку, використання інформаційних систем, мереж, ресурсів та інформаційних технологій, створених на основі застосування сучасної обчислюваної та комунікаційної техніки [9]. Отже, саме ці процеси повинні бути предметом правового регулювання інформаційних відносин і спрямовуватись на задоволення інформаційної потреби окремої людини, держави та суспільства загалом, виконувати функцію забезпечення рівних можливостей для суб'єктів інформаційних відносин.

Аналіз наукових джерел свідчить про поширення думки, що інформаційний регулятор стосується лише публічної сфери, у його використанні значну роль відіграють засоби масової інформації й інтернет [10, с. 47-48]. Але як бути із приватною інформацією стосовно людини, її особистого або сімейного життя, здоров'я, персональних даних, таємниці кореспонденції, телефонних розмов тощо. Захист таких прав закріплено на рівні Конституції України [11], Закону України «Про захист персональних даних» [12], Цивільного кодексу України [13], інших нормативно-правових актів.

Що стосується публічної інформації, то варто зауважити, що її досить часто пов'язують з інститутом гласності, відкритості та прозорості діяльності публічних органів державної влади, інших публічних органів держави, місцевого самоврядування, які повинні надати можливість вільного доступу до публічної інформації. Зокрема, такий доступ забезпечується Законом України «Про порядок висвітлення діяльності органів державної влади та органів місцевого самоврядування в Україні засобами масової інформації». Відповідно до ст. 2 цього Закону, органи держав- ної влади й органи місцевого самоврядування зобов'язані надавати засобам масової інформації повну інформацію про свою діяльність через відповідні інформаційні служби органів державної влади й органів місцевого самоврядування, забезпечувати журналістам вільний доступ до неї, крім випадків, передбачених Законом України «Про державну таємницю», не чинити на них будь-якого тиску і не втручатися в їхній виробничий процес. Засоби масової інформації можуть самостійно досліджувати й аналізувати діяльність органів державної влади й органів місцевого самоврядування, їх посадових осіб, давати їй оцінку, коментувати [14].

Наступним Законом, який реґламентує порядок здійснення та забезпечення права кожного на доступ до інформації, що перебуває у володінні суб'єктів владних повноважень, інших розпорядників публічної інформації, $\epsilon$ Закон України «Про доступ до публічної інформації». Метою цього Закону $\epsilon$ забезпечення прозорості та відкритості суб'єктів владних повноважень, створення механізмів реалізації права кожного на доступ до публічної інформації (ст. 2) [15].

Законом України «Про доступ до судових рішень» [16] гарантовано відкритість діяльності судів загальної юрисдикції, яку забезпечено доступом до судових рішень, судових наказів, постанов, вироків, ухвалених судами загальної

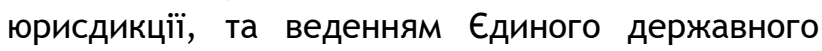
реєстру судових рішень.

Інформаційні відносини в публічній сфері реґламентовано також Законом України «Про рекламу», яким визначено засади рекламної діяльності в Україні, урегульовано відносини, що виникають у процесі виробництва, розповсюдження та споживання реклами [17]. Соціальна реклама $\epsilon$ важливим інструментом формування громадянського суспільства і засобом комунікації між суспільством і державою [18]. О.Ю. Міщенко зазначає, що реклама завдяки своїй соціальній функції здатна формувати поведінкові настанови в суспільстві, сприяти виникненню нових потреб та цінностей [19, с. 390]. На думку Д.О. Маріц, у сучасному світі можливе необ'єктивне подання інформації, адже за допомогою таких інструментів, як засоби масової інформації, кіноіндустрія, інформація може бути спотворена, перекручена залежно від інтересів власника засобу масової інформації, інтересів інших зацікавлених осіб [20, с. 115]. У такому разі якраз чітке регулювання інформаційних відносин має надзвичайно велике значення. Правове регулювання таких 
відносин $є$ одним із видів соціальних регуляторів i поширюється як на приватну, так і на публічну сфери відносин. Зокрема, В.А. Ромащенко зазначає, що впровадження правових регуляторів в інформаційне суспільство триває і досі, відбувається за нормами міжнародного та національного права [21, с. 100].

Варто зазначити, що в сучасному інформаційному просторі поширене застосування договірних відносин, які відіграють важливу роль в інформаційних відносинах. Щодо цього А.Д. Корецький наголошує, що договірне регулювання використовують у всіх галузях права. Водночас у законодавстві немає єдиних принципів реґламентації договірних відносин. Це призводить до того, що В кожній галузі права намагаються сконструювати власні норми, що регулюють порядок укладення, виконання, зміни чи розірвання договорів, без урахування набутого іншими галузями досвіду вирішення таких питань (а інколи і всупереч йому), використовують угоди в умовах юридичного вакууму [22, с. 154]. Щодо договірних відносин О.А. Кодинець зазначає, що інформаційними зобов'язаннями $є$ такі правовідносини, у яких одна сторона має право вимагати від іншої надання чи передання майнових прав на інформацію або утримання від учинення дій, спрямованих на надання чи передання таких прав іншим особам. Лише певна кількість договірних зобов'язань, об'єктом яких є інформація, може належати до категорії інформаційних договірних зобов'язань [23, с. 249]. Якщо предметом договору, наприклад, є створення інформації чи утримання від розголошення інформації, у такому разі договір $\epsilon$ підставою для виникнення інформаційних правових відносин. Останнім часом усе активніше застосовуються договори про надання інформаційно-консультативних послуг, наприклад надання інформації про ринок нерухомості, працевлаштування, відпочинку тощо.

В Україні, напевно, протягом десятиріччя ведеться наукова дискусія стосовно того, чи інформаційне право - це окрема галузь права, чи міжгалузева наука? У дослідженні предмета та методів інформаційного права Р.А. Калюжний і А.Г. Марценюк, на мій погляд, цілком обґрунтовано зазначають: «<...> Інформаційне право можна визначити як прикордонну галузь між публічним і приватним правом. Серед складних, ієрархічних багатопорядкових підсистем, що формують українську правову систему, інформаційне право становить комплексну міжгалузеву науку в загальній системі національного права. Через предмет суспільних відносин інформаційне право пов'язане з іншими галузевими та міжгалузевими інститутами права, тобто відбувається агрегація інститутів з інформаційним правом» [24, с. 6]. На мій погляд, така думка $є$ виправданою, інформаційне право можна віднести до міжгалузевого інституту права. Правове регулювання інформаційних відносин опосередковується з різними галузями права, наприклад: цивільним, адміністративним, кримінальним, господарським тощо.

Деякі науковці, як-от Л.Л. Попов, Ю.І. Мігачев, С.В. Тихомиров, уважають, що інформаційне право являє собою окрему самостійну галузь, водночас стверджують, що інформаційні відносини регулюються конституційним, адміністративним, цивільним та міжнародним правом [25, с. 25]. Така позиція $є$ досить дискусійною. Якщо інформаційні відносини регулюються конституційним, адміністративним, цивільним та міжнародним правом, то відносити його до самостійної галузі, напевно, як мінімум не логічно. Про це свідчить й аналіз Закону України «Про інформацію» [26], яким регулюються відносини щодо створення, збирання, одержання, зберігання, використання, поширення, охорони, захисту інформації. За порушення законодавства України про інформацію, відповідно до ст. 27 цього Закону, наступає дисциплінарна, цивільно-правова, адміністративна або кримінальна відповідальність, що свідчить про його міжгалузевий характер. Крім того, норми права, які регулюють інформаційні відносини, не пов'язані єдиним методом та механізмом правового регулювання, оскільки містяться в різних галузях права. Тому відносити інформаційне право до самостійної галузі права, напевно, не можна. Водночас воно відіграє досить гармонійну роль міжгалузевого права, без якого в сучасних умовах інші галузі права не зможуть обійтися.

Отже, можна сказати, що під правовим регулюванням інформаційних відносин треба розуміти наявність міжгалузевих правових норм, які регулюють публічно-приватні відносини щодо створення, збирання, зберігання, поширення, використання, знищення тощо інформацією, на підставі яких виникають правові інформаційні відносини між суб'єктами.

Висновки. Аналіз законодавчих актів із питань правового регулювання інформаційних відносин в Україні свідчить, що регулювання інформаційних відносин потребує подальшого вдосконалення. Нині інформаційні правовідносини мають міжгалузевий характер і виникають на стику суміжних 
неоднорідних галузей права, спільним об'єктом регулювання для яких $\epsilon$ інформація. Тому можна сказати, що правове регулювання інформаційних відносин являє собою специфічну правову категорію, яка полягає в такому: 1) єдність об'єкта правового регулювання (інформація); 2) наявність правових норм у різних галузях права щодо регулювання інформаційних відносин та відповідальності за їх порушення; 3) інформаційні відносини мають публічно-приватний характер правового регулювання.

\section{Література}

1. Словник іншомовних слів / за ред. О.С. Мельничука. Київ, 1977. 775 с.

2. Пеньков Е.М. Социальные нормы-регуляторы поведения личности. Некоторые вопросы методологии и теории. Москва : Мысль, 1972. 198 с.

3. Йоффе О.С. Юридические нормы и человеческие поступки. Актуальные вопросы советского гражданского права. Москва : Юрид. Лит., 1964. С. 10-51.

4. Литвиненко Т.А., Плахтєєва В.І. Словник-довідник юридичних термінів. Харків : Форт, 2010. 190 c.

5. Кохановська О.В. Правове регулювання у сфері інформаційних відносин : монографія. Київ : Нац. акад. внутр. справ України, 2001. 211 с.

6. Правова доктрина України : у 5ти т. / Нац. акад. прав. наук України. ; редкол. : В.Я. Тацій (гол.) та ін. Харків : Право, 2013. Т. 5. 864 с.

7. Бєляков К.І. Інформація у праві : теорія і практика. Київ : КВІЦ, 2006. 118 с.

8. Петров Є.В. Інформація як об'єкт цивільно-правових відносин : автореф. дис. ... канд. юрид. наук: 12.00.03. Харків, 2003. 20 с.

9. Про Концепцію Національної програми інформатизації : Закон України від 4 лютого 1998 р. № 75/98. Відомості Верховної Ради України. 1998. № № 27-28. Ст. 182 (із змінами).

10. Мазепа М.М., Дубровський І.М. Право в системі соціальних регуляторів / за заг. ред. О.П. Угровецького. Харків, 2012. 91 с.

11. Конституція України : Закон України від 28 червня 1996 р. № 254к/96. Відомості Верховної Ради України. 1996. № 30. Ст. 141.

12. Про захист персональних даних : Закон України від 1 червня 2010 р. № 2297-VI. Відомості Верховної Ради України. 2010. № 34. Ст. 481 (із змінами).

13. Цивільний кодекс України. Відомості Верховної Ради України. 2003. № № 40-44. Ст. 356 (із змінами).
Правове забезпечення адміністративної реформи

14. Про порядок висвітлення діяльності органів державної влади та органів місцевого самоврядування в Україні засобами масової інформації : Закон України від 23 вересня 1997 р. № 539/97. Відомості Верховної Ради України. 1997. № 49. Ст. 299 (із змінами).

15. Про доступ до публічної інформації : Закон України від 13 січня 2011р. № 2939-VI. Відомості Верховної Ради України. 2011. № 32. Ст. 314 (із змінами).

16. Про доступ до судових рішень : Закон України від 22 грудня 2005 р. № 3262-IV. Відомості Верховної Ради України. 2006. № 15. Ст. 128 (із змінами).

17. Про рекламу : Закон України від 3 липня 1996 р. № 270/96. Відомості Верховної Ради України. 1996. № 39. Ст. 181 (із змінами).

18. Щодо віднесення рекламних роликів до соціальних. URL: https://www.nrada.gov.ua/shhodovidnesennya-reklamnyh-rolykiv-sotsialnyh/ (дата звернення: 05.10.2020).

19. Мищенко Е.Ю. Реклама как регулятор поведения в обществе потребления. Теория и практика общественного развития. 2015. № 12. С. 390-392.

20. Маріц Д.О. Деструктивна пропаганда у кінематографі. Деструктивна пропаганда : шляхи протидіі та проблеми відповідальності : матеріали Науково-практичної конференції, м. Київ, 21 травня 2015 р. Київ : ТОВ «ІВА», 2015. С. 114-116.

21. Ромащенко В.А. Правове регулювання інформаційного суспільства в Україні. Підприємництво, господарство і право. 2016. № 9. С. 100-104.

22. Корецкий А.Д. Теоретико-правовые основы учения о договоре / отв. ред. П. П. Баранов. Санкт-Петербург : Юридический центр «Пресс», 2001. 211 с.

23. Кодинець А.О. Цивільно-правове регулювання зобов' язальних інформаційних відносин. Київ : Правова єдність ; Алерта, 2016. 580 с.

24. Калюжний Р.А., Марценюк А.Г. Предмет та методи інформаційного права. Правова інформатика. 2008. № 3 (19). С. 5-9.

25. Попов Л.Л. Информационное право : учебник. Москва : Норма ; Инфра-М, 2010. 495 с.

26. Про інформацію : Закон України від 2 жовтня 1992 р. № 2657-XII. Відомості Верховної Ради України. 1992. № 48. Ст. 650 (із змінами).

Грохольський В. Л., доктор юридичних наук, професор, перший проректор Одеського державного університету внутрішніх справ 